\title{
Relationship between Fifth Grade Students' Reading Interest and Reading Ability
}

\author{
Siti Aisyah ${ }^{1}$, Ratih Purnamasari ${ }^{2}$, \\ Primary School Teacher Education Study Program, Pakuan University, Bogor, Indonesia \\ seaaisyah@gmail.com
}

Received: November $21^{\text {st }}, 2020$

Revised: January $18^{\text {th }}, 2021$

Accepted: January $22^{\text {nd }}, 2021$

\begin{abstract}
The purpose of this study was to determine the relationship between reading interest and students' reading comprehension ability. Research approach using quantitative with correlational study method. The subjects of this study were students of class VA and VB at SD Negeri Karya Bhakti totaling 90 students. The sample was taken by 47 students, then this study was obtained using a five-scale questionnaire for the Reading Interest and Reading Comprehension Ability variables using tests. Therefore, from the data obtained, it was found that a moderate relationship between reading interest and reading comprehension ability was seen from the accumulated calculation results, which was $30 \%$ such as using the time to read books in the library, while $70 \%$ is influenced by other factors such as students who are motivated by the teacher to increase reading interest so that students can to read a comprehension and other factors are also influenced from outside of students, namely when doing tasks, students are guided and assisted by parents. . Based on the results of the research above, it can be concluded that there is a positive relationship between Reading Interest and Reading Comprehension Ability in class VA and VB students of SD Negeri Karya Bhakti Odd semester of the 2019/2020 academic year.
\end{abstract}

Keywords: elementary school; reading comprehension ability, reading interests.

\section{INTRODUCTION}

Education can be said to be of quality if it produces quality graduates, education is an activation process in which there is an atmosphere of teaching and learning. One of the drivers of the success of education from learning activities. Effective learning activities include reading, which is a process carried out by individuals to obtain changes in knowledge and to achieve learning goals in the affective, cognitive, and psychomotor domains. Learning objectives will not be achieved properly if the learning process does not go well (Gunawan, 2019).

Reading interest is very important in learning. Therefore, reading needs to be nurtured and accustomed to since school age. By having a penchant for reading books, students will be embedded in having a high reading interest. The 
interest in reading books is not only for books available in libraries or only fiction books, but also for textbooks in schools.

However, there are still students who are not interested in reading (Halim, Hermita, \& Kurniaman, 2020), this has also received attention from the 2018 Program for International Student Assessment (PISA) placing Indonesia in 74th place out of 79 countries, aka sixth from the bottom in the category of reading, science, and mathematics. Meanwhile, the lowest score obtained by Indonesia is in the Reading category, which is 371 (OECD average 489). Based on a survey conducted by UNESCO in 2012 on reading interest in 61 countries. Indonesia is only 0.001 percent or is in the lowest rank of the countries surveyed.

Based on the results of observations and interviews with the homeroom teacher of class V SD Negeri Karya Bhakti, the homeroom teacher stated that some grade $\mathrm{V}$ students whose reading ability is still low are less than KKM 78. One of the low abilities is due to the lack of interest in reading, many students do not visit the library. during breaks, but playing in class and in the schoolyard, as well as many who snack and there are still students who are not fluent in reading. This is the lack of reading interest of students, the homeroom teacher also explained if reading awareness was lacking. Reading interest needs to be used from an early age, when a child is just learning to read, the child's reading interest will get used to it when faced with reading. But children's reading interest is still low, lack of interest in reading is influenced by the desire of oneself and the environment. In general, reading interest is only carried out at certain times, some students still feel lazy with reading activities because they think that reading is boring.

The relationship between reading interest and reading ability has received attention from several researchers, including Setiawan (2016: 40), explaining that there is a positive relationship between reading interest and reading comprehension ability in elementary students. The higher the reading interest, the higher the reading comprehension ability, conversely the lower the reading interest, the lower the reading comprehension ability of elementary students. Khofiah (2015: 70) states that reading interest and reading comprehension ability have a positive relationship. So any increase in the independent variable, namely reading interest, will affect the increase in the dependent variable, namely reading comprehension ability. Based on the results of observations made at SD Negeri 32 Banda Aceh, it was found that there were some IV students of SD Negeri 32 Banda Aceh whose reading ability was less than the KKM 75.

Based on the background of the problems described above, the authors are interested in researchig to find out how much the relationship between reading interest and reading comprehension ability of students in class $V$ at SD Negeri Karya Bhakti, Cipanas District, Cianjur Regency. 
In connection with this title, the limitation of the problems in this study are as follows: 1) The literacy movement in schools has not been maximally carried out in all subjects. 2) The low reading interest in students is still low. 3 ) Students think that reading is a boring activity. 4) Lack of reading comprehension skills of students in answering questions.

Based on the background description, problem identification and problem limitation above, the research problem can be formulated as follows: Is there a relationship between reading interest and reading comprehension ability of students in Class V at SD Negeri Karya Bhakti, Cipanas District, Cianjur Regency?

Reading interest is the desire and activity of a person that comes from within himself to carry out all activities such as reading, writing and others. As Rahayu et al (2016: 191), Hendrayani and Ade (2017: 239) suggest that reading interest is a strong motivation and desire for someone to read, a high desire to read in a person can lead to a passion to read so that someone will always trying to get reading material to meet his needs.

Many factors affect the reading interest of students who come from within or from outside, as stated by Mustika and Lestari (2016: 19), Wicaksono (2017: 405), Sahrandi (2018: 143) revealed that there are several factors influencing interest in reading, these factors include factors from within the individual and factors from outside the individual. These two factors contribute to growing someone's reading interest.

Increasing reading interest in students needs to be done with several efforts and methods that must be done by families, communities and educational institutions in line with Karim (2014: 52) and Kasiyun (2015: 88) states that increasing interest in reading can be started when children are still not able to read. Activities that can be done among the family are storytelling, the availability of reading at home, discussing the contents of the books that are read, visiting bookstores, getting used to giving gifts of books.

Reading interest will not be created if it is not used from an early age so reading interest must be grown from an early age so that students can get used to reading, as Rachmadi (2019: 19) and Darmadi (2018: 152) argue that growing interest in reading from an early age is positive and It has many benefits, among others: it can instill a habit of happy reading because books are a storehouse of knowledge and for young children,books can add new vocabulary so that children will be good at communicating and developing creativity.

From the various theories above, it can be synthesized that reading interest is an activity carried out with perseverance and strength in reading, the emergence of reading interest in a person can be influenced by several factors, namely interest that comes from nature and interests that arise due to external influences. Reading interest needs to be grown from an early age so 
that someone will get used to reading by involving the family environment and school.

Reading comprehension is an activity to understand the content of reading, Rahayu's opinion (2015: 17), and Firman (2018: 13) Reading comprehension is a reading activity to understand the content of the reading, both express and implied from the reading material.

The purpose of reading comprehension is so that we know the problems we read down to very detailed matters, Khasanah and Cahyani (2016: 162), and Kaban (2015: 6) argues that the purpose of reading comprehension is to carry out the reading process to understand the ideas conveyed by the author.

Some factors affect reading ability, generally, the reading ability referred to is addressed by a person's understanding of the reading they read. According to Salam (2018: 25) Factors that affect reading comprehension: factors cognitive processes, general knowledge, reasoning abilities, intelligence factors, socioeconomic factors, sensory factors, fluency factors Reading comprehension, one of the reading skills that is in the highest order, to maintain reading, it is necessary to have external encouragement in improving reading comprehension. According to Simbolon (2019-16) improving reading by reciprocal teaching is a learning activity that takes place using reading strategies used by good readers to enhance others.

Based on the theoretical studies that have been put forward by experts on the ability to read comprehension, it can be synthesized that the ability to read comprehension is a reading activity that understands reading content, text, tables, diagrams or graphs quickly and accurately, reading comprehension is influenced by several factors, namely cognitive factors. , general knowledge, reasoning abilities, intelligence, socioeconomic, sensory, fluency. Improve reading comprehension.

\section{METHOD}

The research was conducted with a correlational approach. This correlation research was carried out on the fifth grade students of SDN Karya Bhakti. Conducted in the even semester of the 2019/2020 school year. The population in this study were all students of grade $\mathrm{V}$ totaling 90 students. The sample used in the study was carried out with the Taro Yamane formula. The total sample of the study was 47 students in grade V. The research aims to determine the relationship between two variables, namely the independent variable $(X)$ in this study is reading interest and the dependent variable $(\mathrm{Y})$ is the ability to read comprehension.

The data collection technique of this research used a questionnaire method and test questions to collect data from students who were selected as respondents to obtain information about the relationship between reading interest and reading comprehension skills of fifth grade students at SDN Karya Bhakti, Cipanas District, Cianjur Regency. 
Instrument testing was carried out on 30 respondents. The validity of the reading interest questionnaire trial of the Pearson Product Moment formula and the reliability test using Cronbach's Alpha calculation. While the validity of the test questions on the reading comprehension ability used the point biserial formula, the reliability test used the KR-20 formula, the difficulty level test, and the distinguishing power test.

Before the statistical hypothesis test is carried out, the research data must first meet the requirements of the analysis using the estimation standard error normality test and regression linearity test. The research method used is a survey research method with correlational techniques.

\section{RESULT AND DISCUSSION}

The description of this research data is grouped into two parts, namely consisting of the dependent variable data group, namely, the results of reading comprehension $(Y)$, and the independent variable data, reading interest $(X)$ which is described in the form of descriptive statistics. Description of each data, namely the lowest score, highest score, range of scores, mean (mean), middle value (median), frequent values (mode), standard deviation (SD), sample variance, and total score.

By the results of the calculation of the regression equation analysis in the transmission diagram image above, it shows that there is a positive relationship and shows the closeness between the two variables provided that the positive correlation variable $Y$ will increase if the variable $X$ increases. If variable $X$ is controlled, variable $Y$ will also be controlled. The correctness of the regression results above is used to test the hypothesis of whether there is a positive relationship between reading interest $(X)$ and students' reading comprehension ability $(Y)$. The functional relationship between $X$ and $Y$ is presented in the form $\hat{Y}=7.76+0.10$ where $X$ is significant.

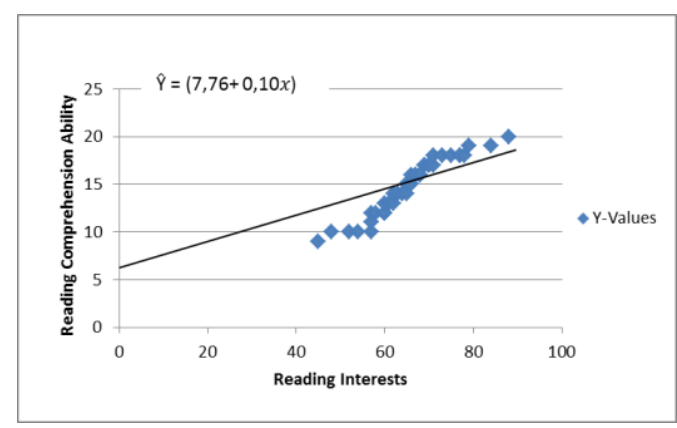

Figure 1.Functional Relationship Scatter Diagram for Reading Interest Variables $(X)$ and Students' Reading Comprehension Ability (Y)

The results of the statistical analysis above show that there is a positive relationship between reading interest and students' reading comprehension ability. This means that the research hypothesis is acceptable because reading interest contributes to reading comprehension skills. The results of the Product Moment analysis show a correlation coefficient of 0.55 . This means that there is a moderate correlation between reading interest and students' reading comprehension ability and its direction is positive. 
Based on the significance test results of the correlation coefficient, the results of the significance test of the correlation coefficient are obtained, namely the hypothesis examiner using the Pearson Product Moment correlation test. The results of the analysis showed a positive relationship between reading interest and reading comprehension ability with the equation $\hat{Y}=7.76+0.10 X$. Furthermore, the results of the significance test of the correlation coefficient obtained tcount $=$ 132.18 while 2.021 and $\mathrm{dk} 45$. So that tcount> ttable is 132.18> 2.021. The comparison of the two values obtained shows that tcount> ttable which shows that reading interest $(X)$ and reading comprehension ability $(\mathrm{Y})$ are significant. Because the correlation coefficient obtained is positive, it means that the higher the reading interest, the higher the reading comprehension ability will be obtained. The relationship between reading interest and students' reading comprehension ability is indicated by a correlation coefficient of 0.55 . The coefficient value shows that there is a moderate relationship between reading interest and reading comprehension ability by using the time to read books in the library, and students can master vocabulary in reading indicated by the coefficient ( $r 2)$ of 0.30 with a coefficient of determination of $30 \%$.

The results of this study are supported by the results of research by Setyowati, Purnomo, Sukardi (2017) that reading interest and reading habits are positively and significantly related to the reading comprehension ability of $55 \%$ in fifth grade elementary school students in the Suroto Cluster ( $r=0.746, R=0.556)$. the relationship between reading interest and reading habits with reading comprehension skills.

In addition, the research conducted by Mulyani and Nurliana (2017) entitled "The Relationship between Reading Interest and Reading Comprehension Ability in Grade IV Students of SD Negeri 32 Banda Aceh" The results of this study indicate a significant level $\alpha=0.05$ and $\mathrm{dk}=\mathrm{n}-2=63-2=61$. The data analysis showed that the regression equation value for reading interest was 48.649 and the reading ability test regression equation value was 0.447 .

Furthermore, "The Relationship between Reading Interest and Reading Ability" has received the attention of several researchers including Setiawan (2016) who explained that there is a positive relationship between reading interest and reading comprehension ability in elementary students. The higher the reading interest, the higher the reading comprehension ability, conversely the lower the reading interest, the lower the reading comprehension ability of elementary students.

The research on the relationship between reading interest and reading comprehension ability was carried out by Khofiah (2015) entitled "The Relationship between Reading Interest and Reading Comprehension Ability in High Grade Students of SD N 1 Karangsari" The results of hypothesis testing showed the correlation coefficient ( $r$ count) $>r$ table. $(0.590>0.234)$ with a significance level 
of $5 \%$ with the number $N=71$. The price of the correlation coefficient indicates a positive relationship between reading interest and reading comprehension ability of high grade students at SD N 1 Karangsari, Pengasih District, Kulon Progo Regency in the 2014/2015 academic year. This means that any increase in reading interest variables will affect the increase in the variable. reading comprehension skills

In addition, the relationship between reading interest and reading comprehension ability was carried out by Octaviani (2017) entitled "The Relationship between Reading Interest and Reading Ability in Indonesian Language Subjects for Class IV Min 1 Lampung Selatan Students" The method used was the product moment correlation with a significant level of $5 \%$. The results of calculations using the product moment correlation formula obtained rcount $=0.977$ and $\mathrm{r} 0.05 ; 47=$ 0.288 , then rcount $>\mathrm{r} 0.05$; 47 . So $\mathrm{HO}$ is rejected, this means that there is a relationship between reading interest and reading comprehension in Indonesian subjects, in a very strong category. The contribution of the influence given by the reading interest variable $(X)$ to reading comprehension $(\mathrm{Y})$ is $95.64 \%$

Referring to the results of research and relevant research, it can be said that reading interest has a relationship with students' reading comprehension ability. Thus learning discipline should be impro to improve learning outcomes.

\section{CONCLUSION}

Based on the discussion of the results of the research that has been carried out, it can be concluded that there is a relationship between reading interest and reading comprehension ability of students in Class V at SD Negeri Karya Bhakti, Cipanas District, Cianjur Regency. There is a positive and significant relationship between reading interest and reading comprehension ability. This is visible. Reading Interest with Reading Ability. Understanding of the correlation value $r$ is 0.55 which means that the relationship between variables is moderate. With the results of the coefficient of determination $\left(r^{2}\right)=0.30$, which means reading interest contributes $30 \%$ to reading comprehension skills.

Based on the overall results of the research conducted, there are several suggestions by the researcher for the next researcher, namely this research uses simple regression analysis techniques, should use more than one factor that affects Reading Interest, so that it can be seen the magnitude of the influence of other factors on Reading Comprehension Ability, and this research can also be used with a case study research method using interesting learning media so that students are interested in reading.

\section{REFERENCES}

Darmadi. (2018). MEMBACA YUK "Strategi menumbuhkan minat baca pada anak sejak usia dini". Bogor : Guepedia Publisher Firman. (2018). Terampil Menulis Karya Ilmiah. Makassar : Aksara Timur 
Gunawan, D. (2019). Developing Scramble-Based Learning Method to Increase Students' Reading and Writing Comprehension. Journal of Teaching and Learning in Elementary Education, 2(1), 16-28. Halim, M., Hermita, N., \& Kurniaman, O. (2020). Analysis of the Ability of Reading Class 1 Basic School Students in State Basic School 009 Kepau Jaya Siak Hulu Kampar District. Tunjuk Ajar: Jurnal Penelitian IImu Pendidikan, 3(1), 77-86.

Hendrayani, A. (2017). Peningkatan Mina Baca dan Kemampuan

Membaca Peserta Didik Kelas Rendah Melalui Penggunaan Reading Corner. Jurnal Penelitian Pendidikan

https://ejournal.upi.edu/index.php/J ER/ article/download/9617/5927

Kaban, S. (2015). Peningkatan Kemampuan Membaca Pemahaman Melalui Pendekatan Saitifik Pada Siswa Kelas V SD Negeri Pondok Labu 12 Pagi Jakarta Selatan. Jurnal IImiah PGSD, 8(2). http://journal.unj.ac.id/unj /index.php/pgsd/article/view/7990

Karim, Y. (2014). Upaya Meningkatkan Minat Baca. Jurnal DEIKSIS, 6(1).

https://journal.lppmunindra.ac.id/ind ex.php/Deiksis/article/viewFile/514/ $\underline{792}$

Kasiyun, S. (2015). Upaya Meningkatkan Minat Baca Sebagai Sarana Untuk Mencerdaskan Bangsa. Jurnal Pena Indonesia, 1(1) https://journal.unesa .ac.id /index. php/jpi/article/download/ 140/61

Khasanah, A., Cahyani, I. (2016). Peningkatan Kemampuan

Membaca Pemahaman Dengan Strategi Question Answer Relationships (QAR) Pada Siswa Kelas V Sekolah Dasar. Jurnal Pedagogik Pendidikan Dasar, $4(2)$.

Khofiah, S. (2015). Hubungan Minat Bca Dengan Kemampuan Membaca Pemahaman Siswa Kelas Tinggi $S D N \quad N$ Karangsari Kecamatan Pengasih Kabupaten Kulon Progo Tahun Ajaran 2014/2015. Semantic Scholar, 2. https://www.semanticscholar.org/pa per/ HUBUNGAN -MINAT-BACADENGAN-KEMAMPUAN MEMBACA-SISWAKhofiah/80fe12 5b1390e351b90a0ae110216161d ef36f33\#paper-header

Mulyani., Nurlian. (2017). Hubungan Antara Minat Baca Terhadap Kemampuan Membaca Pada Siswa Kelas IV SD Negeri 32 Banda Aceh. Jurnal Tunas Bangsa.

https://tunasbangsa.stkipgetsempe na.ac.id/?journal=home\&page $=$ artic le\&op=download\&path\%5B\%5D =4 6\%3Fjournal\%3Dhome\&path\%5B\% $\underline{5 \mathrm{D}=4}$

Mustika, I., Lestari, D, R. (2016). Hubungan Minat Baca Dan Kebiasaan Membaca Karya Sastra Terhadap Kemampuan Menulis Puisi. Jurnal STKIP Siliwangi, 5(2). http://www.e- 
journal.stkipsiliwangi.ac.id/index.ph p/semantik/article/view/291/221.

Oktaviani, E, M. (2017). Korelasi Minat Baca Terhadap Membaca Pemahaman Pada Mata Pelajaran Bahasa Indonesia Siswa Kelas VI MIN 1 Lampung Selatan. Vol 02.

Rachmadi, G, A. (2019). EASY PARENTING : Stratergi

Menumbuhkan Minat Baca Sejak Usia Dini. Bandung : Edwrite Publishing.

Rahayu, I, T, L. (2016). Hubungan Minat Membaca dan Motivasi Belajar Materi Menulis Karangan Pada Warga Belajar Materi Menulis Karangan Pada Warga Belajar Kejar Paket C Di PKBM Al-Firdaus Kabupaten Serang. Jurnal Untirta 1(2).

http://jurnal.untirta.ac.id/index.php/E -Plus/ article/download/1165/930

Sahrandi, A. (2018). Mekanisme Menumbuh Kembangkan Minat
Baca Siswa Madrasah Di Perpustakaan. Jurnal Pendidikan Islam , 8 http://ejournal.iaidalwa.ac.id/index. php/jpi/article/view/105

Salam. (2018). Membaca Komprehensif (Strategi Pemahaman bacaan). Gorontalo : Ideas Publishing

Setiawan, B. (2016). Hubungan Antara Minat Membaca dengan Kemampuan Membaca Pemahaman pada Siswa SD. Jurnal Unika Soegijapranata, 1. http://repository.unika.ac.id/13162/

Simbolon, E, M. (2019). Tuturan dalam Pembelajaran Berbicara dengan Metode Reciprocal Teaching. Surabaya: Media Sahabat Cendikia

Wicaksono, A. (2017). Pengkajian Prosa Fiksi. Yogyakarta : Penerbit Garudhawaca 